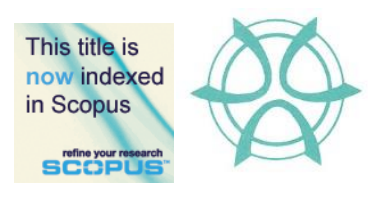

PLANNING MALAYSIA:

Journal of the Malaysian Institute of Planners

VOLUME 15 ISSUE 1 (2017), Page 295 - 304

\title{
RISE OF ECLECTICISM IN THE 21ST CENTURY MALAYSIAN MOSQUE ARCHITECTURE
}

\author{
Amir Hossein Zekrgoo ${ }^{1}$ \\ ${ }^{1}$ Kulliyyah of Architecture \& Environmental Design \\ INTERNATIONAL ISLAMIC UNIVERSITY MALAYSIA
}

\begin{abstract}
A stylistic survey of Malaysian mosque architecture shows four distinct trends: 1) Traditional style, which covers most of the mosques that were built before the country's independence in 1957; 2) Colonial style that was influenced by Indian Mughal architecture, was followed partly after independence, and continued for a while after that; 3 ) Modern trend began with the National Mosque completed in 1965, and scattered mosques that were built after the National Mosque until the end of the 20th century; and 4) Mosques that were erected in the 21st century, which can be generally explained by the term 'eclectic' design. Eclecticism gained rapid momentum in the field of Malaysian mosque architecture since the dawn of the current century. Significant eclectic mosques that have transformed the scene and skylines of major Malaysian cities have often been heavily financed by the government - an indication of conscious choice of direction. This paper aims at providing a categorisation of the process of evolution of contemporary mosque architecture in Malaysia, not based on independent stylistic tendencies, but under three major historical/thematic phases: 1) Independence and Departure from Tradition; 2) Middle Eastern Inspirations; and 3) Rise of eclecticism, with an emphasis on the last phase, i.e. rise of eclecticism in the 21st century. Masjid Wilayah, completed in August 2000, was chosen as a case study because it is the first major eclectic mosque born in the 21st century, incorporating some six established styles, and also the most comprehensive example.
\end{abstract}

Keyword: Eclecticism, 21st century, style, architecture, mosque, Malaysia

Date Received: $30^{\text {th }}$ April 2016

Date of Acceptance: $30^{\text {th }}$ October 2016 
Amir Hossein Zekrgoo

Rise of Eclecticism in the 21st Century Malaysian Mosque Architecture

\section{INTRODUCTION}

The evolution of Malaysian mosque architecture, from its traditional timber prototypes that related and connected it to the large family of Southeast Asian vernacular architecture, to the unique and independent styles that emerged after independence, all the way to the colourful eclectic developments in the $21 \mathrm{st}$ century, exhibits a rapid transformation of political thought, aesthetic values and socio-economic identity. Adjustment to this change has not been easy, as it brought about challenges at various levels - personal, cultural and national. But it paved the way for problem-solving and creativity at a higher level. The ongoing change expanded the views in the realm of architecture and environmental design, and led to opportunities for new developments. At the same time, it disturbed the tempo of life and introduced a lifestyle that is more exciting and less peaceful. The evolution of architecture in any society is a byproduct of the evolution of mindset, social norms and aesthetic values of the said society. On the other hand, the appearance of new buildings changes a city-scape and, in a timespan, imposes a new mindset, norms and values on the citizens. Eclecticism, which involves borrowing forms and styles rooted in another culture, and using them in a single monument/complex is an embodiment of this challenge.

\section{PHASE 1: INDEPENDENCE AND DEPARTURE FROM TRADITION}

Modernism, which was initially formed and developed in mid-19th century Europe and America as a movement in art and literature, was soon spread to other aspects of life and to non-Western societies, not only as an artistic form of expression, but as a world view that favoured new over tradition. Modernism is characterized by a deliberate rejection of tradition. Malaysian mosque architecture before its independence in 1957 can be explained as having certain style(s) of traditional timber architecture built from heavy hardwood species called cengal (Balanocarpus heimii), constructed in post and beam system with no metal fasteners to join the timber members (Ismail Said, 2001). Kampung Laut Mosque, located in Kota Baru, Kelantan is the oldest existing example of traditional Malay Mosque architecture. It is in many respects similar to Malay house architecture (Figure 1).

Traditional Malaysian mosque architecture is part of a family of vernacular tradition in Southeast Asia that includes Indonesian archipelago, Malay Peninsula, Thailand and the Philippines. "What has so far been emphasized in recorded history are the pyramid or meru type of timber roof which are either placed on stilts or which cover masonry colonnaded wall with tiled floor" (Mohamad Tajuddin Mohamad Rasdi, 2012)." Meru is a sacred mythical mountain in Indian religious traditions (Hinduism, Buddhism and Jainism) and considered as the central axis of the universe, both physical and metaphysical. As most of the population of Southeast Asian countries were followers of Hinduism and Buddhism before converting to Islam, the term survived mainly due to its 
PLANNING MALAYSIA

Journal of the Malaysia Institute of Planners (2017)

cosmological connotations that associate it with the concept of the place of worship - on the confluence of heaven and earth.

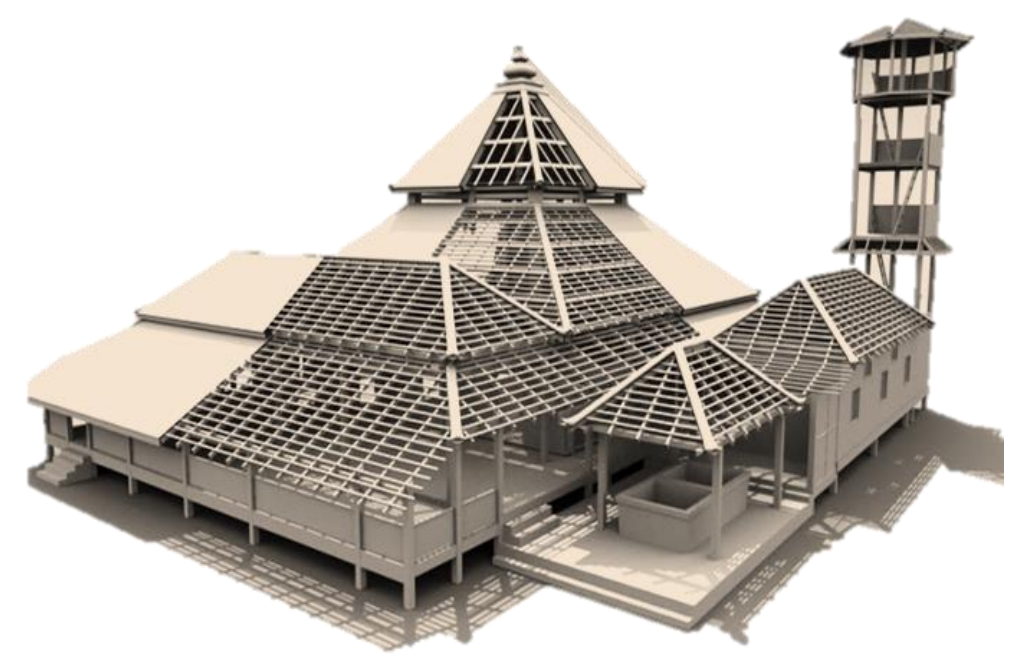

Figure 1 A Scaled Model of Kampung Laut Mosque

After Independence, the first outstanding monument that stressed on the country's independence as a nation on the one hand, and on its Islamic inclination on the other, was the National Mosque or Masjid Negara. Unlike the typical traditional Malay mosques, which were closely associated in their general characters with Malay house architecture and conversed in the same visual language of its surroundings, the National Mosque communicated a different message using a different tone.

This monument, built from concrete, made a statement that projected country's new mindset and preferred future direction - not to continue with the old traditions, but a deliberate departure from them. Although the National Mosque's semi-open umbrella-shaped roof may have some formal resemblance to Malay traditional mosques, it projects a different spirit; it loudly resonates a political slogan of nationalism adorned with religious embellishments in monumental scale. A similar building with a white roof, known as 'Hero's Mausoleum' (Makam Pahlawan), was erected within the National Mosque's compound. It further echoed the political/national spirit. Makam Pahlawan, completed in 1965, is the burial ground of a number of Malaysian leaders (Figure 2). 
Amir Hossein Zekrgoo

Rise of Eclecticism in the 21st Century Malaysian Mosque Architecture

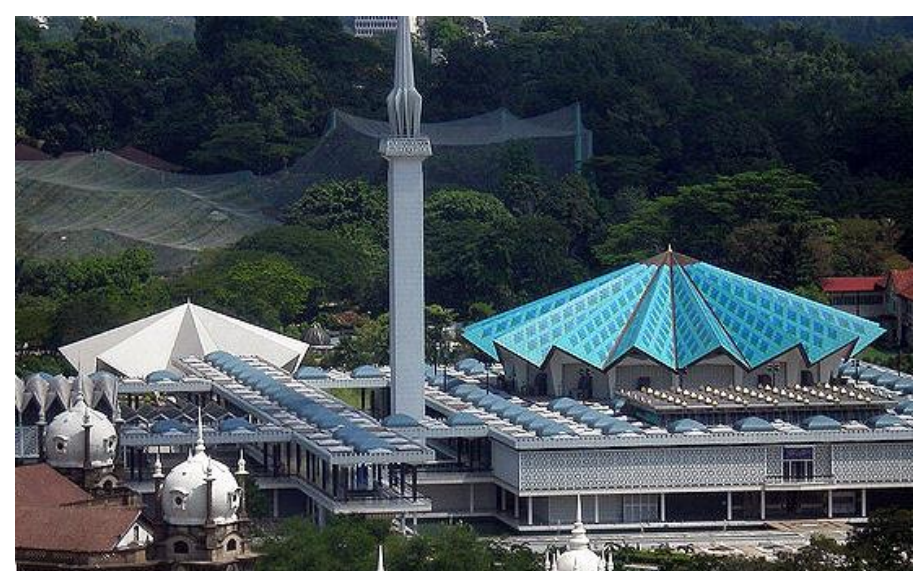

Figure 2 National Mosque or Masjid Negara, completed in 1965 is the larger structure with patterned roof on the right while the smaller building with similar roof structure on the left is the Hero's Mausoleum (Makam Pahlawan).

\section{PHASE 2: MIDDLE EASTERN INSPIRATIONS}

The concept of umbrella-shaped roof for mosques stayed fashionable for a short while, but by 1980's the idea "...declined rapidly in popularity amongst the architects, as onion-shaped dome regained its earlier prominence" (Abdul Halim Nasir, 2004). The prominence of onion-shaped domes in Malaysia's history in the past few centuries, however, was not necessarily connected to Islam or any religion for that matter, as it was also used extensively in the secular colonial buildings by western non-Muslim rulers. No wonder then that the earliest recorded mosque in Malaysia with onion-shaped dome, Ubudiah Mosque in Perak (built in 1913-1917), was designed by a British architect Arthur Benison Hubback (1871-1948). An overview of the architectural elements reveals a strong inspiration from the Mughal architecture of India.

The trend of mosque architecture in post-independence Malaysia, however, unveils a drastic change of inclination. Some scholars have put an effort to provide a timeline for the dominance of architectural styles that emerged after 1957 until the end of the 20th century and vaguely called it modern (A. Ghafar Ahmad, 1999). While buildings are called colonial simply for having onionshaped domes, it seems an over simplified or even misleading to include wellestablished architectural styles such as those from Mughal India, Safavid Iran and Ottoman Turkey that mark the majority of mosques erected during the period with the term 'Modern.'

Malaysia, after her independence, gradually exercised an open-door policy that had significant impact on the country's economy and culture, and as a result, a wide range of styles - originating from the Subcontinent to the Middle East, and even North Africa and Spain - appeared on the plain of mosque architecture. Among them, mosques inspired by Turkey and Iran designs gained 
PLANNING MALAYSIA

Journal of the Malaysia Institute of Planners (2017)

more popularity, especially with the major state funded mosques. An outstanding example is the Blue Mosque or Shah Alam Mosque, the largest mosque in Malaysia that was completed in 1988. This mosque which is also known by the name of its founder as Sultan Salahuddin Abdul Aziz Mosque, has been reported by the Malaysian Ministry of Tourism in 2011 to be Malaysia's largest mosque and the second largest in Southeast Asia. First glance at the pictures of the mosque one could easily imagine that its location is somewhere in Iran or Turkey. The form of the dome as well as the glazed blue tiles that entirely cover it, and coloured windows seem Persian. While the overall plan with the four tall minarets shows Ottoman influence (Figure 3). From the outer appearance of the Blue Mosque, no Malay element is noticeable; although the inner skin of the dome is covered with wooden panels that reflect Malay traditional architecture.

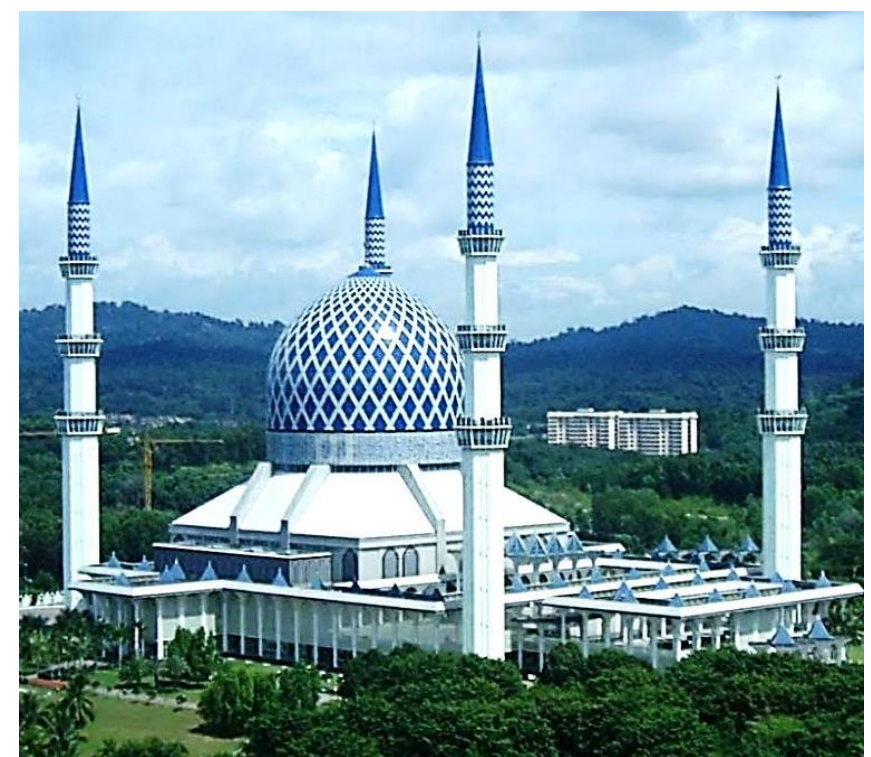

Figure 3 Blue Mosque Shah Alam, Selangor, Malaysia

\section{PHASE 3: RISE OF ECLECTICISM}

As stated earlier, the trend of adopting foreign styles of mosque architecture on Malaysian soil picked up during the last two decades of the 20th century. During this period architects experimented with various forms, styles, colours and material, and as a result, a large number of small and medium size mosques of a very wide spectrum of styles and designs were erected. The fast process of mosque construction changed the landscape of Malaysia significantly. Most of the newly built mosques were clearly influenced by certain well-established styles or even a certain well-known mosque; a Qubbat al-Sakhra Mosque in Jerusalem, for instance, has often been imitated. Though most scholars have stuck 
Amir Hossein Zekrgoo

Rise of Eclecticism in the 21st Century Malaysian Mosque Architecture

to the general categorization of 'traditional, colonial and modern,' Mohamad Tajuddin Mohamad Rosdi (2012) steps a little further and uses terms that are more specific. He divides Malaysian mosque architecture historically into three periods: "the Early Vernacular, the Colonial Adaptation and Modern - Post Modern.

From the dawn of the 21st century, however, combining various architectural styles in a single mosque became more of a conscious trend. Funding bodies, which in most cases were government institutions, encouraged incorporating foreign styles into mosque design. This was in line with promoting tourism under the open door policy. Architects were given free hand to come up with creative ideas, and financial support was there to implement them. A systematic amalgamation of styles began to sprout, which in the process gave birth to a rather new trend in Malaysian mosque architecture that may be designated as "Eclectic Style" (Amir H. Zekrgoo, 2014).

Eclectic architecture is a product of amalgamation of elements from various structural, spatial and decorative forms that carry features representing specific and distinct cultures in a single structure (Turner, 1996). Although in an overall assessment formal similarities were observed between Post Modernism and Eclecticism, while studying it in Malaysian mosque architecture context one realizes a fundamental difference. Post Modernism in architecture was a reaction to Modern Functionalism in western architecture, which was perceived a failure. This was partly because Modern architecture had undermined ornamentation at the cost of function, and Post Modernism was there to revive the aesthetic aspect of mosques.

Malaysian Eclecticism, on the other hand, had a total different background. Modernism, in the technical/stylistic sense, never actually found manifestation in Malaysian mosques; moreover, mosques were never deprived of their ornamentation. In other words, architects of the 21st century Malaysia experimented with formal and structural elements of existing styles in the Muslim world in search of new compositions while their efforts were not in any way a reaction or objection to the existing conditions.

From among a number of major eclectic mosques that the author has surveyed, Masjid Wilayah, the grand regional mosque of Kuala Lumpur, seems a distinct example.

Completed in August 2000 Masjid Wilayah is the first major eclectic mosque born in the 21 st century. While discussing the subject of eclecticism in Islamic architecture, the author had a tradition of taking his students to this mosque every semester for over a decade. In its construction, refined features borrowed from renowned traditional styles are blended with sophisticated modern technology. Studying the structure as well as its decorative components one can trace the presence of features from the Sultan Ahmed Mosque of Istanbul (Turkey), Shah Mosque in the Naqsh-e Jahan Square of Isfahan (Iran), the Taj 
PLANNING MALAYSIA

Journal of the Malaysia Institute of Planners (2017)

Mahal of Agra (India), and Egyptian and Moroccan features, alongside native traditional elements (Figure 4).

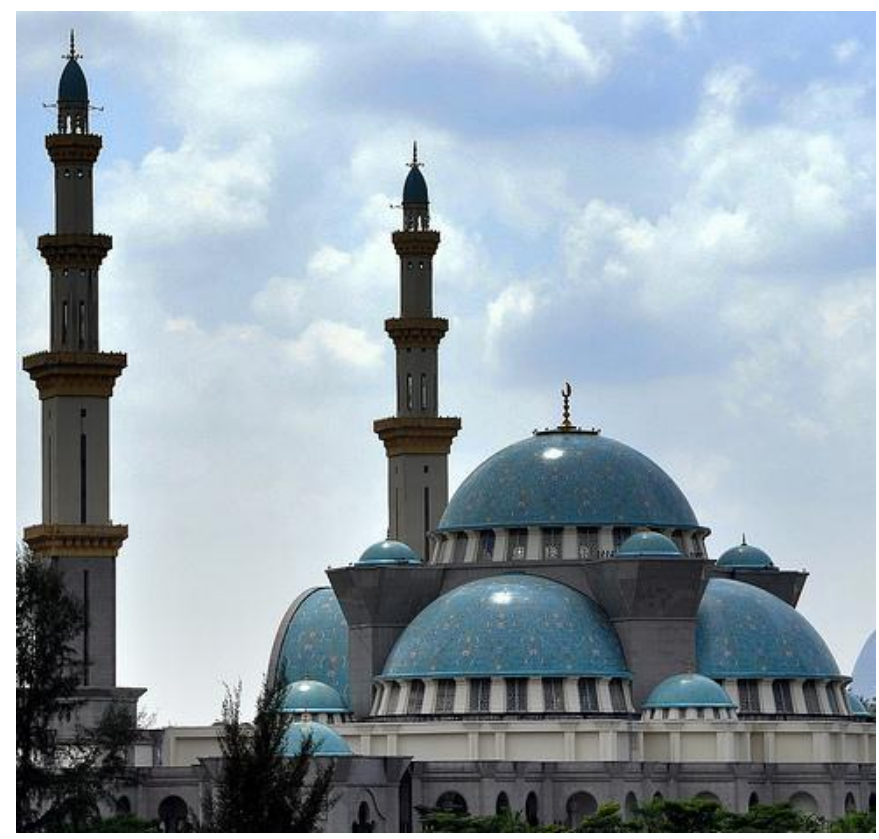

Figure 4 Masjid Wilayah, KL, Malaysia

\section{FINDINGS AND DISCUSSION}

DOMES: The mosque's 33 domes were arranged in a typical Ottoman style - a central main dome surrounded and supported by half-domes and smaller domes. From afar the mosque brings to mind the Sultan Ahmet Mosque of Istanbul (1609-1616), but the colourful skin of the dome with turquoise blue tiles in the background adorned with floral motifs in white and yellow with black contours are inspired by the Shah/Imam Mosque of Isfahan (1611-1629).

MINARETS: Wilayah Mosque's two 96 meter minarets follow a mix of Egyptian and Ottoman styles. The minarets are divided into 5 segments that reflect the Turkish example, whereas the whole style of minarets is Egyptian. Egyptian minarets are based on a square plans, and are constructed on different levels and parts (usually three). The minarets of the Wilayah Mosque are four-sided at their foundation and at their highest level they become eight-sided. They resemble the minarets of Abu al-Abbas al-Mursi Mosque (1775) in Alexandria.

PORTICO AND MIHRAB: The main arch that leads to the prayer area is a structure that is special and inspiring. It combines the Persian Muqarnas and 
Amir Hossein Zekrgoo

Rise of Eclecticism in the 21st Century Malaysian Mosque Architecture

Parchi Kari. Parchin Kari, also known as Pietra Dura is a technique of inlay of semi-precious colourful stones usually in marble. The end result is highly polished to get a glossy surface. An art employed by ancient Iranian craftsmen that was perfected by Indian artisans during the Mughal Empire (1526-1707). The famous Taj Mahal (in Agra, India) is adorned with the best examples of Parchin Kari. Some of the master craftsmen from Agra were in fact commissioned to make geometric, arabesque and calligraphy panels on the façade of the main entrance as well as the mihrab of Masjid Wilayah (Figure 5 \& 6).

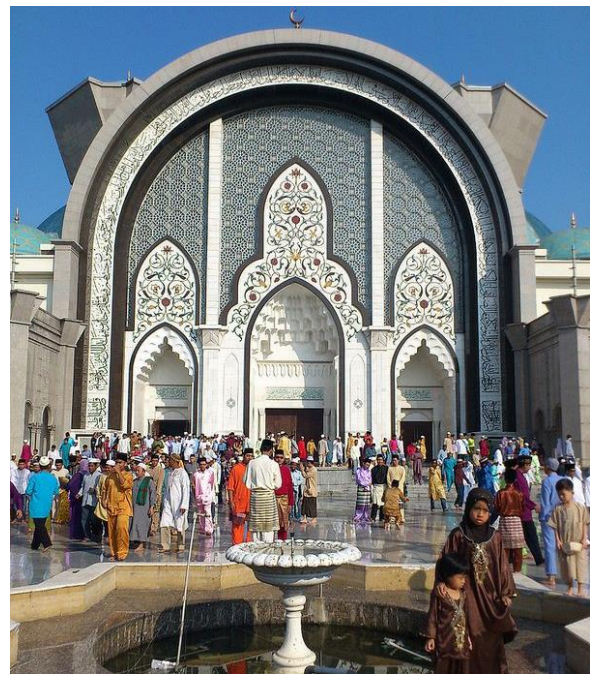

Figure 5 Portico, Masjid Wilayah (Picture by Azman Aziz)

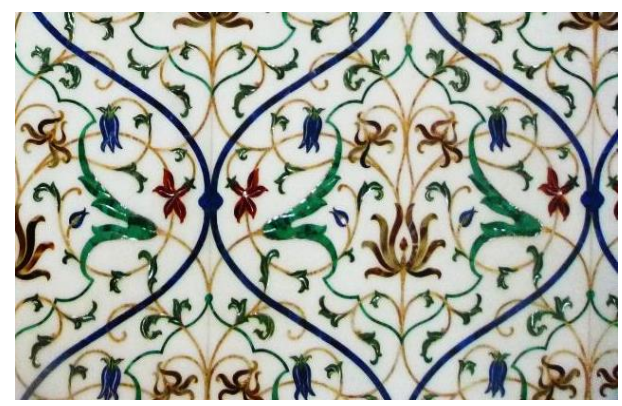

Figure 6 Parchinkari with Semi-Precious Stones and Mother of Pearls, Mihrab of Masjid Wilayah

(Picture by Amir Zekrgoo)

ARCHES: Masjid Wilayah has five covered porchs, marked by horse-shoe arches in Moroccan style, surrounding its large courtyard. (Figure 8)

MINBAR, DOORS \& SCREENS: Traditional Malaysian art of wood carving is seen in the making of all the doors, the screen partitions that mark women's prayer area on the second floor. The large and tall minbar that stands to the right side of the mihrab is the most prominent wooden element in the mosque. The wood carving is done by Malay craftsmen from Kelantan and Terengganu (Figure 9). 


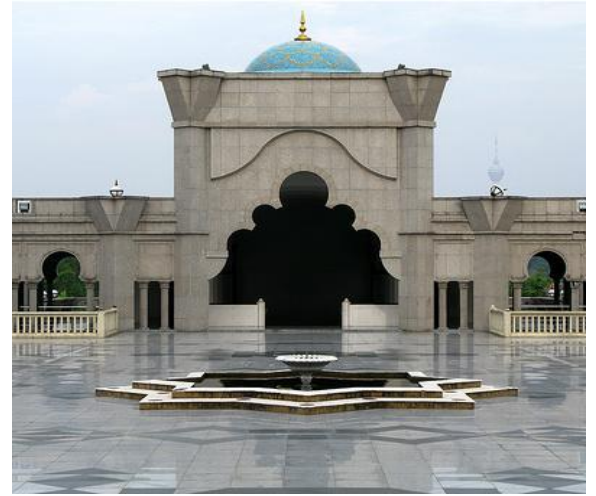

Figure 7 Moroccan Arches Surrounding Masjid Wilayah's Courtyard. (Picture by Amir Zekrgoo)

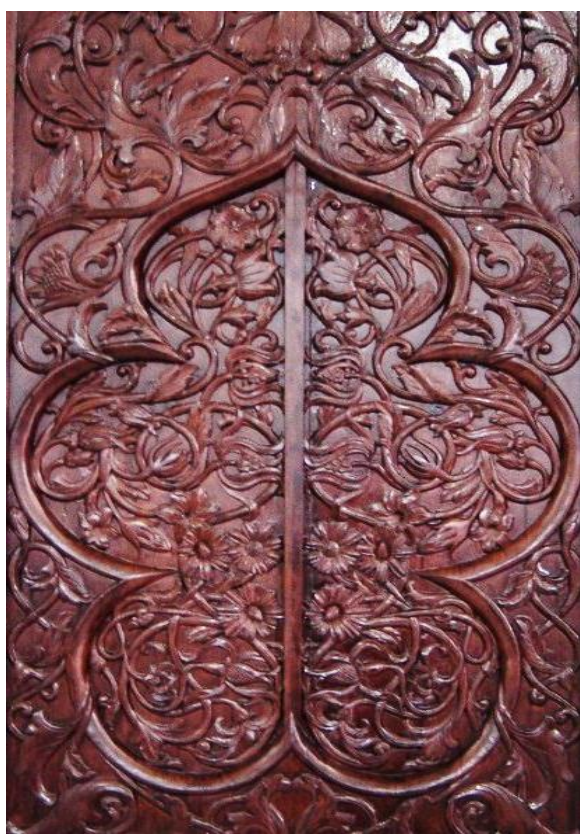

Figure 8 Traditional Malay

Woodcarving with Floral Motifs Inspired by Local Plants, Door to the Main Prayer Hall, Masjid Wilayah (Picture by Amir Zekrgoo)

\section{CONCLUSION}

Malaysian mosque architecture underwent drastic transformation since its independence in 1957. Before independence the mosques shared general characteristics of South-east Asian vernacular timber architecture. Masjid Negara marks the first departure from tradition towards modernism. After the erection of this historic landmark, until the end of the 20th century, Malaysian urban landscapes were witness to the sprout of countless mosques that were inspired mostly by the Middle Eastern mosques. The result was colourful structures with no clear stylistic direction. The 21st century however displays a conscious direction towards treating eclecticism as a style, a deliberate bringing of multiple styles under a single roof, which Masjid Wilayah in Kuala Lumpur seems to be a comprehensive and impressive example. Eclectic mosque architecture of Malaysia needs wider and deeper investigation, as the change of form and structure of the mosques dictates different social behaviour of the Muslims in their collective acts of worship. Acceptance or resistance towards such changes can be regarded as an indications of the degree of willingness to depart from indigenous cultural and aesthetic values. 


\section{REFERENCES}

A. Ghafar Ahmad (1999). The architectural styles of mosques in Malaysia: from vernacular to modern structures. In Proceedings Symposium on Mosque Architecture: The Historic and Urban Developments Of Mosque Architecture (Volume 2) (pp. 147-163). King Saud University, Riyadh, Saudi Arabia. https://cap.ksu.edu.sa/en/Symposiume_on_Mosque_Architecture

Abdul Halim Nasir (2004) (translated by Omar Salahuddin Abdullah). Mosque architecture in the Malay World. Bangi: Penerbit Universiti Kebangsaan Malaysia.

Amir H. Zekrgoo (2014). Emergence of eclecticism as style: new approaches to mosque architecture in Malaysia. Firooze Islam, Journal of Research on Islamic Architecture and Urbanism, 1(1), 25-32.

Ismail Said (2001). Art of woodcarving in timber mosques of Peninsular Malaysia and Southern Thailand. Jurnal Teknologi, 34, 45-56.

Mohamad Tajuddin Mohamad Rasdi, (2012). Traditional Islamic architecture of Malaysia. Kuala Lumpur: Dewan Bahasa dan Pustaka.

Turner, J. (1996). The Grove dictionary of art. New York: Oxford University Press. 